\title{
Correction to: P2X7R-dependent regulation of glycogen synthase kinase $3 \beta$ and claudin-18 in alveolar epithelial type I cells of mice lung
}

\author{
K. Barth $^{1} \cdot$ R. Bläsche ${ }^{1}$ A. Neißer ${ }^{1}$ S. Bramke ${ }^{1}$ J. A. Frank ${ }^{2}$ - M. Kasper ${ }^{1}$
}

Published online: 11 December 2018

c) Springer-Verlag GmbH Germany, part of Springer Nature 2018

\section{Correction to: Histochem Cell Biol (2016) 146:757-768 https://doi.org/10.1007/s00418-016-1499-3}

In the original publication of the article, there is an error in the Abstract section. In line 17, it should read "increased" instead of "decreased". The corrected sentence is provided below:

Furthermore, alveolar epithelial cells from $\mathrm{P} 2 \mathrm{X}^{-1-}$ animals showed increased levels of GSK-3 $\beta$ protein and its inactive form GSK-3 $\beta$ (pS9).

\section{Kasper}

michael.kasper@tu-dresden.de

1 Institute of Anatomy, Medical Faculty "Carl Gustav

Carus", Technical University Dresden, Fetscherstr. 74,

01307 Dresden, Germany

2 San Francisco VA Medical Center, University of California, San Francisco, 4150 Clement St, Box 111D, San Francisco, CA 94121, USA 